also as chairman of the Cardiganshire War Agricultural Executive Committee. Dr. Bryner Jones will continue to act as one of the Minister's liaison officers for Wales.

\section{Veterinary Surgeons and Military Service}

A JoINT statement was issued by the Ministry of Labour and National Service and the Ministry of Agriculture and Fisheries on October 5 announcing the setting up of the Army Service Veterinary Selection Committee to advise the Ministers concerned on the recruitment of veterinary surgeons for military service in their professional capacity. In order to provide full representation of the interests of veterinary surgeons in private practice, an additional member representing the National Veterinary Medical Association has been appointed to the Committee. This Committee has considered the cases of veterinary surgeons who have graduated since January 1, 1940, and who at present comprise the 'pool' from which the men needed for service in the R.A.V.C. will be recruited as required. Notifications of the Committee's decisions in these cases are being sent to the assistants concerned and also to their employers. It is expected that the number of veterinary surgeons thus made arailable to the R.A.V.C. will go some way, at least, to meet immediate needs. It is essential, however, in order to meet urgent military contingencies, to have a reserve of veterinary surgeons who may be drawn upon when necessary. It has accordingly been decided that the 'pool' shall be extended to include all veterinary surgeons born on or after January 1, 1914. The cases of these men will be dealt with on their merits, in accordance with the arrangements set out in the earlier announcement.

\section{Economic Flux Density in Large Transformers}

Is a paper read before the Institution of Electrical Engineers in London, D. J. Bolton pointed out that technical developments may at any time make it possible to increase the working densities in electrical machines and so enable a larger output to be obtained from a given frame-size and weight of active materials. The present paper assumes that an increase of transformer flux density is technically feasible, and tries to discover whether it is economically desirable. Only a single situation is examined, and only two, fairly large, sizes of transformer, such as would be used in the lower-voltage sections of the British Grid, are considered. The results are emphatically against any such increase, and in favour of densities lower than those in use at present.

\section{Edible and Poisonous Plants of the Pacific Islands}

A small technical manual, prepared by Dr. E. D. Merrill of Harvard University, has been issued by the War Department of the United States, giving descriptions of the "Emergency Food Plants and Poisonous Plants of the Islands of the Pacific" (T.M. 10-420. Superintendent of Documents, U.S. Government Printing Olfice, Washington, D.C.). Although the manual is intended "to aid the individual who becomes separated from his unit" to sustain himself, it has a wider field of interest. More than a hundred of the more common edible tropical plants are figured, and each is accompanied by a short description with notes as to what parts may be eaten and how they should be prepared, together with a list of the plant names in local tongues. Nearly a dozen of the more virulent poisonous plants are also included. The simple, clear habit drawings are admirable. Occasionally human figures are included to indicate the scale, a practice which, perhaps, might have been followed more often. However, the whole makes an excellent handbook.

\section{The Night Sky in January}

FULL moon occurs on Jan. 10d. 10h. 09m. U.T., and new moon on Jan. 25d. 15h. $24 \mathrm{~m}$. The following conjunctions with the moon take place : Jan. 6d. 18h., Mars $8^{\circ}$ N.; Jan. 8d. 04h., Saturn $2^{\circ}$ N. ; Jan. 13d. 11h., Jupiter $0 \cdot 7^{\circ} \mathrm{S}$.; Jan. 22d. 21h., Venus $2^{\circ} \mathrm{S}$.; Jan. 22d. 23h., Mercury $0 \cdot 1^{\circ} \mathrm{S}$. The following occultations of stars brighter than magnitude 6 take place : Jan. 4d. 16h. $14.6 \mathrm{~m}$. $\xi^{2}$ Ceti $(D) ; J a n .8 d$. 19h. 31.8m., 64 Orio $(D)$; Jan. 9d. 00h. 52.5m., 68 Orio $(D)$; Jan. 15d. 04h. 15.1m., 308B Leon $(R)$; Jan. $16 \mathrm{~d}$. $05 \mathrm{~m} .03 \cdot 9 \mathrm{~s} ., b$ Virg $(R)$. The times refer to Greenwich and $D$ and $R$ refer to disappearance and reappearance respectively. Mercury is in inferior conjunction on Jan. 8. In the middle of the month it rises and sets an hour before the sun, the times at the end of the month being $6 \mathrm{~h} .27 \mathrm{~m}$. and $14 \mathrm{~h} .29 \mathrm{~m}$. Venus, a morning star, rises at $4 \mathrm{~h} .37 \mathrm{~m}$., 5h. $12 \mathrm{~m}$., and $5 \mathrm{~h} .44 \mathrm{~m}$. at the beginning, middle and end of the month respectively. Mars, in the constellation of Taurus, is stationary on Jan. 10. The planet can be seen through a great part of the night, being due south at $21 \mathrm{~h} .30 \mathrm{~m}$., $20 \mathrm{~h}$. $34 \mathrm{~m}$., and $19 \mathrm{~h}$. $42 \mathrm{~m}$. at the beginning, middle and end of the month, the times of setting on the corresponding dates being $5 \mathrm{~h} .45 \mathrm{~m} ., 4 \mathrm{~h} .50 \mathrm{~m}$., and $4 \mathrm{~h}$. Jupiter, in the constellation of Leo, rises at $20 \mathrm{~h} .07 \mathrm{~m}$., $19 \mathrm{~h} .04 \mathrm{~m}$. and $17 \mathrm{~h} .50 \mathrm{~m}$. at the beginning, middle and end of the month and is visible throughout the night. Saturn, in the constellation of Taurus, sets about an hour later than Mars at the beginning and middle of the month, and on Jan. 31 it sets at $4 \mathrm{~h} .39 \mathrm{~m}$. The earth reaches perihelion on Jan. 4 , its distance from the sun being then $91,447,000$ miles. There will be a total eclipse of the sun on Jan. 25, partly visible as a partial eclipse at Greenwich. The eclipse begins at Greenwich on Jan. 25d. 16h. 29m., but the magnitude of the eclipse will be only about $1 / 50$, and this will occur about sunset. The Quadrantid meteors are due on Jan. 3 and 4 ; the radiant of this shower is at R.A. 15h. 20 m., Dec. $+50^{\circ}$.

\section{Announcements}

THE Council of the British Cotton Industry Research Association announces that Dr. F. C. Toy has been appointed to succeed Sir Robert Pickard, who is relinquishing the post of director of research which he has filled for the last seventeen years. Dr. Toy has held the position of deputy director of the Association since he joined the Shirley Institute staff thirteen years ago. Dr. D. W. Hill has been appointed to succeed Dr. Toy as deputy director. Sir Robert Pickard has accepted the post of consultant to the Association.

ERRATUM. In connexion with the paragraph on the Duddell Medal award to Mr. J. Guild in Nature of December 11, p. 686, reference was made to $\mathrm{Mr}$. Guild's work on the improved goniometric spectrometer in collaboration with "the late $\mathrm{Mr}$. George Watts". We are informed that Mr. Watts is still chairman of Messrs. E. R. Watts and Son, Ltd., and takes an active part in the daily work of the firm's factory. 